\title{
Efficiency of Detergents against Microbial Biofilm Growth in Kuching, Sarawak
}

Elexson Nillian*, Sheryı Melinda, Micky Vincent and Leslie Bilung

Department of Molecular Biology, Faculty of Resource Science and Technology, University Malaysia Sarawak, 94300, Kota Samarahan, Sarawak, Malaysia

*Corresponding author: Elexson Nillian, Department of Molecular Biology, Faculty of Resource Science and Technology, University Malaysia Sarawak, 94300, Kota Samarahan, Sarawak, Malaysia, E-mail: nelexson@frst.unimas.my

Received date: October 4, 2016; Accepted date: October 26, 2016; Published date: October 31, 2016

Copyright: (c) 2016 Nillian E, et al. This is an open-access article distributed under the terms of the Creative Commons Attribution License, which permits unrestricted use, distribution, and reproduction in any medium, provided the original author and source are credited.

\begin{abstract}
Biofilms formed on these surfaces are the main cause of contamination in the final product. The attachment of bacteria to food product or the product contact surfaces leads to serious hygienic problems and economic losses due to food spoilage. Detergent is commonly used as cleaning product to mitigate the growth of microbial on the food product surface and in any food supply chain process. In this study, the efficiency of commercial detergent was analyzed against single cell of foodborne pathogens to biofilm form; Klebsiella pneumonia, Bacillus cereus and Staphylococcus aureus. The antibacterial activity of three detergent; Detergent 1, Detergent 2 and Detergent 3, were evaluated by measuring the diameter zone of inhibition using disc diffusion test. $S$. aureus showed the highest zone inhibition which is $27.67 \pm 0.577 \mathrm{~mm}$ (mean \pm standard deviation) whereas $K$. pneumonia showed the lowest zone of inhibition which is $19.97 \pm 0.577 \mathrm{~mm}$ against Detergent 4 . Minimum inhibitory concentration (MIC) and minimal bactericidal concentration (MBC) were determined using 96-well microtiter plates. All detergents exhibited inhibitory activity against bacteria tested. D3 showed the lowest MIC and MBC of $S$. aureus at $0.390 \mathrm{mg} / \mathrm{ml}$ and $0.781 \mathrm{mg} / \mathrm{ml}$ respectively, whereas $K$. pneumonia has the highest MIC and MBC at $3.125 \mathrm{mg} / \mathrm{ml}$ and $6.25 \mathrm{mg} / \mathrm{ml}$. The studies have been further done to test minimum bactericidal eradication concentration (MBEC) in related to biofilm eradication capacity. The MBEC result showed Detergent 3 could eradicate biofilm of $S$. aureus at 3.125 $\mathrm{mg} / \mathrm{ml}$. Thus, the appropriate detergent can be incorporated into food product surfaces and processing lines to mitigate the biofilm growth that potentially cause disease outbreak in future.
\end{abstract}

Keywords: Biofilm; Detergent; Klebsiella pneumonia; Bacillus cereus, Staphylococcus aureus

\section{Introduction}

Detergent is important in daily life because it assists in cleaning and removing dust, dirt and germs that attach on contaminated surface. In response to the increasing concern about food preparation by food handlers due to cross contaminating of bacteria that may be pathogenic, thus the use of detergent is necessary in cleaning phase [1]. The goal of detergent is to totally eradicate food poisoning microorganisms in any food surfaces such as utensils, facilities or equipment in the food processing line [2].

In the food industry, the use of detergents is an important part of the manufacturing practices to prevent any aggregation regime and subsequent microbial biofilm formation. The failure in removing the bacteria from food contact surfaces may lead to the transmission of foodborne illness. Food residue on the food product surfaces may provide nutrient and encourage the microorganism to grow and form biofilm. Adhesions of microorganism to equipment surface such as unsanitized utensils enable to direct or indirectly transmit into food, food processing lines [3] and domestic environment [4]. Food contaminated with pathogenic bacteria such as Bacillus cereus and Staphylococcys aureus can cause severe risk to human being. Bacillus cereus is a spore forming bacterium and mainly known as causative agent in foodborne disease. Transmission disease is through consumption of contaminated food, improper food handling, cooking, storage and heating [5].

According to Maris [6], the exact mechanism of action of a detergent is not easy to determine. The notion of 'target' in the bacterial cell, frequently toward the antibiotics, is not clear for detergents. Hence, it can be difficult to distinguish the primary stage which is characteristic of the mode of action and the secondary stage of the consequence of the action of the detergents. In the food industry, the use of detergents is an important part of the manufacturing practices to prevent aggregation regime and subsequent microbial biofilm formation. However, various detergents which are extensively used in food industries may not be really effective against some microorganisms especially in biofilm form. Bacterial colonization of food processing equipment and facilities is the main concern and is a potential source of contamination of foods that may lead to spoilage or transmission of food borne pathogens. Therefore, this study investigated the effects of detergents on the growth biofilm of Klebsiella pneumonia, Bacillus cereus and Staphylococcus aureus in Kuching, Sarawak.

\section{Methodology}

\section{Preparation of detergents}

K. pneumonia, B. cereus and S. aureus isolates were collected from Microbiology Laboratory, Faculty of Resources Science and Technology, UNIMAS. Then, three types of commercial detergents were purchased from supermarket in Kota Samarahan, Kuching Sarawak. Namely Detergent 1, Sodium tripolyphosphate (STPP) based, Detergent 2 Alkylpolyglucoside (APG) based and Detergent 3 Linear alkylbenzene sulphonate (LAS) based.

The stock solution was prepared according to Rukayadi et al. [7] with some modifications. The detergents $(0.1 \mathrm{~g})$ were diluted in DMSO (10\%) to obtain the final $10 \%$ of stock solution as it is the minimum 
concentration, which could inhibit the growth of B. cereus, $K$. pneumonia and $S$. aureus. Chlorhexidine (CHX) (1, 1-hexamethylenebis5-p-chlorphenyl biguanide), purchased from Sigma Chemical (St Louis, MO, USA), was used for standard control and was dissolved in sterile-distilled water to get $10000 \mu \mathrm{g} / \mathrm{ml}(1 \%$ stock solution).

\section{Disc diffusion test}

Sterile filter paper discs (6 mm diameter) (Schleicher and Schuell, Dassel, Germany) were placed on MHA plates and $20 \mu \mathrm{l}$ of $10 \%$ stock solution for each detergent was impregnated on the discs. A disc with different dilution of detergent was placed on plate containing organism suspension. Negative control (10\% of DMSO) was included in the assay. After 24 hour of incubation at $37^{\circ} \mathrm{C}$, the plates were examined for clear zones The method proposed by Rukayadi et al., [7] was modified as follows: First, the detergents was diluted in $10 \%$ of DMSO, and followed by 2 -fold dilution in the test wells. Thus the final concentration of DMSO was serially decreased.

\section{The determination of Minimum inhibitory concentrations (MICs) and minimal bactericidal concentrations (MBCs)}

MICs and MBCs tests were performed in 96-well microtiter plates according to the method described in the CLSI M7-A6 guidelines (2012). MICs for K. pneumonia, B. cereus and $S$. aureus isolates were determined using McFarland standard $\left(5 \times 10^{6} \mathrm{CFU} / \mathrm{ml}\right)$ by diluting 1:1000 using TSB. Each antibacterial agent was diluted 1:10 in TSB containing $5 \times 10^{3} \mathrm{CFU} / \mathrm{ml}$ inoculums. The dilutions started from wells in column 12 of the microtiter plates. Therefore, column 12 of the microtiter plates contained the highest concentration of antibacterial, while column 3 contained the lowest concentration. Column 2 served as the positive control (antimicrobial agent-free wells, only medium and inoculum), and column 1 is the negative control (only medium, no inoculum, no antibacterial agent).

After 24 hour of incubation at $37^{\circ} \mathrm{C}$, the MIC was measured as the lowest concentration of antimicrobial agent resulting in complete inhibition of visible growth. For the MBC determination, wells with no visible growth were used. The medium (approximately of $100 \mu \mathrm{l}$ ) of each well was removed and was spread onto MHA plates and was incubated at $37^{\circ} \mathrm{C}$ for $24 \mathrm{~h}$ (or until visible growth in the positive control). MBC is defined as the lowest concentration of antimicrobial agent, at which the bacteria in cultures were killed or had the lowest concentration with no visible growth on MHA plates.

\section{Minimum bactericidal eradication concentration (MBEC)}

To measure MBECs of the detergents, adhering cells in the 96-well microtiter plates were filled with $200 \mathrm{ml}$ of 2 -fold dilutions of the stock solution. Dilutions started from the wells in column 12 of the microtiter plate. Column 2 served as the positive control (medium and inoculum) and Column 1 was the negative control (only medium). The plates were then incubated at $37^{\circ} \mathrm{C}$ for $24 \mathrm{~h}$.

In order to determine the MBECs, the biofilms at the bottom of the treated wells were rinsed and then scarred with a metal loop and were spread over the surface of MHA plates. The plates were incubated at 37 ${ }^{\circ} \mathrm{C}$ for $24 \mathrm{~h}$ and the MBEC was determined as the lowest concentration of antibacterial agent, at which no bacterial growth was observed on MHA plates. All experiments were performed in triplicate.

\section{Statistical analysis}

The data was obtained after measuring the diameter zone of inhibition and were subjected to one way analysis of variance (ANOVA) to determine the differences among the detergents defined at $p<0.05$. The corresponding variables would be more significant $(\mathrm{p}<0.05)$ if the absolute $\mathrm{F}$ ratio is larger and the $\mathrm{p}$-value becomes smaller. All measurements were carried out in triplicate and the results were reported as the mean \pm standard deviation (SD) of independent trials. Data analysis was carried out using the Minitab 16 statistical package (Minitab Inc., State College, PA, USA).

\section{Results}

\section{Disc diffusion test}

This study examined the efficiency of detergents against bacteria namely, Klebsiella pneumonia, Bacillus cereus and Staphylococcus aureus by measuring the zone of inhibition using disc diffusion method. These three types of bacteria are likely involved in association with foodborne outbreak.

\begin{tabular}{|l|l|l|l|l|}
\hline \multirow{2}{*}{ Detergents } & \multicolumn{2}{|c|}{ Concentration (\%) } & \multicolumn{3}{|c|}{ Zone of inhibition (mm) } \\
\cline { 3 - 5 } & & Klebsiella pneumonia & Bacillus cereus & Staphylococcus aureus \\
\hline Detergent 1 & 100 & $16.97 \pm 0.577$ & $18.00 \pm 0.000$ & $22.33 \pm 1.1555$ \\
\hline & 10 & $\mathrm{NI}$ & $10.67 \pm 0.577$ & $15.00 \pm 1.000$ \\
\hline Detergent 2 & 100 & $17.97 \pm 0.577$ & $20.67 \pm 1.528$ & $25.00 \pm 1.000$ \\
\hline & 10 & $10.67 \pm 0.577$ & $12.67 \pm 0.577$ & $17.33 \pm 0.577$ \\
\hline Detergent 3 & 100 & $19.97 \pm 0.577$ & $24.33 \pm 0.577$ & $27.67 \pm 0.577$ \\
\hline & 10 & $12.67 \pm 0.577$ & $14.33 \pm 0.577$ & $19.33 \pm 0.577$ \\
\hline Note: Mean \pm Standard deviation, $\mathrm{n}=3$; NI: No Inhibition & & & \\
\hline
\end{tabular}

Table 1: Average diameter of zone of inhibition of detergents on Klebsiella pneumonia, Bacillus cereus and Staphylococcus aureus. 
The antibacterial activity of detergents have been investigated at different concentration which is the minimum $10 \%$ and maximum $100 \%$ against $K$. pneumonia, B. cereus and $S$. aureus are shown in Table 1 . The determinations were done in triplicate and the mean values $\pm \mathrm{SD}$ were presented.

Since there are No Inhibition (NI) for Detergent 1 in $10 \%$ concentration toward $K$. pneumonia, the maximum concentration has been selected for further studies. As a result, D3 was the most effective while D1 had less or no activity, and was not really effective as compared to D2 and D3. There is a significant difference $(\mathrm{p}<0.05)$ on the effects of detergents toward these bacteria.

The highest zone of inhibition of D3 was obtained against $S$. aureus for both concentration of $100 \%$ and $10 \%$ at $27.67 \pm 0.577$ and $19.33 \pm$ 0.577 respectively. Meanwhile, for B. cereus the concentration of D3 at $10 \%$ and $100 \%$ were $14.33 \pm 0.577$ and $24.33 \pm 0.577$. Whereas, $K$. pneumonia has the least zone of inhibition at $19.97 \pm 0.577$ and 12.67 \pm 0.577 for $100 \%$ and $10 \%$ concentration respectively, as compare to $S$. aureus and B. cereus.

\section{Minimum inhibitory concentration (MIC) and minimum bactericidal concentration (MBC)}

From the Table 2 and Table 3, it shows the result of minimum inhibitory concentration of D3 possessed the lowest MIC and MBC value of $0.390 \mathrm{mg} / \mathrm{ml}$ and $0.781 \mathrm{mg} / \mathrm{ml}$ respectively on $\mathrm{S}$. aureus. This indicates that lower concentration of D3 is needed to inhibit and kill this bacteria growth. While, the MIC of D3 that can inhibit the bacterial growth for B. cereus and $K$. pneumonia were $3.125 \mathrm{mg} / \mathrm{ml}$ and it showed that these bacteria were killed at the concentration of $6.25 \mathrm{mg} / \mathrm{ml}$.

\begin{tabular}{|l|l|l|l|}
\hline \multirow{2}{*}{ Detergents } & \multicolumn{3}{|l|}{ Minimum Inhibitory Concentration (MIC) (mg/ml) } \\
\cline { 2 - 4 } & Klebsiella pneumonia & Bacillus cereus & $\begin{array}{l}\text { Staphylococcus } \\
\text { aureus }\end{array}$ \\
\hline Detergent 1 & 12.5 & 12.5 & 12.5 \\
\hline Detergent 2 & 6.25 & 6.25 & 3.125 \\
\hline Detergent 3 & 3.125 & 3.125 & 0.39 \\
\hline
\end{tabular}

Table 2: Minimum inhibitory concentration value of detergents on bacterial strains.

\begin{tabular}{|l|l|l|l|}
\hline \multirow{2}{*}{ Detergents } & \multicolumn{3}{|l|}{ Minimum Bactericidal Concentration (MBC) (mg/ml) } \\
\cline { 2 - 4 } & Klebsiella pneumonia & Bacillus cereus & $\begin{array}{l}\text { Staphylococcus } \\
\text { aureus }\end{array}$ \\
\hline Detergent 1 & 50 & 25 & 25 \\
\hline Detergent 2 & 12.5 & 12.5 & 3.125 \\
\hline Detergent 3 & 6.25 & 6.25 & 0.781 \\
\hline
\end{tabular}

Table 3: Minimum bactericidal concentration value of detergents on bacterial strains.

D1 has the highest MIC value of $12.5 \mathrm{mg} / \mathrm{ml}$ against all three bacteria and the concentration that needed to kill the bacteria was at $25 \mathrm{mg} / \mathrm{ml}$ to $50 \mathrm{mg} / \mathrm{ml}$ against $S$. aureus, B. cereus and $K$. pneumonia respectively. Therefore, D1 is needed in higher concentration to kill and inhibit the growth of these pathogens as compared to D2 and D3. Meanwhile, the MIC and MBC for D2 against these bacteria was slightly higher than D3. As shown in Table 2 and Table 3 . While $K$. pneumonia was observed to have the highest MIC and MBC value toward detergents with a range in between $6.25 \mathrm{mg} / \mathrm{ml}$ to $50 \mathrm{mg} / \mathrm{ml}$. Hence, $K$. pneumonia is more resistant toward detergents at very low concentration and was killed at very high concentration.

\section{Minimum bactericidal eradication concentration (MBEC)}

The MBECs for $S$. aureus is the lowest than B. cereus and $K$. pneumonia which apply to all detergents. As seen in Table 4 , $S$. aureus has MBECs of $3.125 \mathrm{mg} / \mathrm{ml}$ for D3, $25 \mathrm{mg} / \mathrm{ml}$ for both D2 and D1. $B$. cereus has MBEC of $12.5 \mathrm{mg} / \mathrm{ml}$ for D3, $25 \mathrm{mg} / \mathrm{ml}$ for D2 as well as D1. $K$. pneumonia has MBECs of $50 \mathrm{mg} / \mathrm{ml}$ for D1 and D2, while D3 has MBEC of $12.5 \mathrm{mg} / \mathrm{ml}$. Based on Table 4, S. aureus biofilm growth could be eradicated at lowest concentration $3.125 \mathrm{mg} / \mathrm{ml}$. In contrast, the eradication concentration for removing biofilm growth of $K$. pneumonia is higher at $50 \mathrm{mg} / \mathrm{ml}$. Thus, detergent 3 has been effective against the growth of bacterial biofilm.

\begin{tabular}{|l|l|l|l|}
\hline \multirow{2}{*}{ Detergents } & \multicolumn{3}{|l|}{$\begin{array}{l}\text { Minimum Bactericidal Eradication Concentration (MBEC) } \\
(\mathbf{m g} / \mathrm{ml})\end{array}$} \\
\cline { 2 - 4 } & $\begin{array}{l}\text { Klebsiella } \\
\text { pneumonia }\end{array}$ & $\begin{array}{l}\text { Bacillus } \\
\text { cereus }\end{array}$ & Staphylococcus aureus \\
\hline Detergent 1 & 50 & 25 & 25 \\
\hline Detergent 2 & 50 & 25 & 25 \\
\hline Detergent 3 & 12.5 & 12.5 & 3.125 \\
\hline
\end{tabular}

Table 4: Minimum bactericidal eradication concentration value of detergents on bacterial strains.

\section{Discussion}

Clean and disinfected food contact surfaces are of the utmost importance in the food industry to control the risk of microbiological contamination in the processing line. Hence in this study, Linear alkylbenzene sulphonate (LAS) based in D3 acquired highest activity toward foodborne pathogens which normally found in household detergent such as dishwashing liquid, where it can remove the stains that in contact with any food residual. LAS is known as anionic surfactant, thus their anionic fatty acid is more active to Gram positive bacteria than Gram negative bacteria [8]. Meanwhile, D2 was Alkylpolyglucoside (APG) based which is the type of non-ionic surfactant. APG are biodegradable when discharged into aerobic aquatic environment [9]. D1 was Sodium tripolyphosphate (STPP) based which assists in removal of fatty soils by maintaining the alkalinity during washing.

Among the three bacteria tested, $\mathcal{S}$. aureus and $B$. cereus are characterized as Gram positive bacteria while $K$. pneumonia is Gram negative bacteria. Therefore, both Gram positive and Gram negative bacteria show differently in their sensitivity toward detergent which is used as an antibacterial agent. This could be attributed to the differences in cell wall structures and composition. Gram negative bacteria have thin layer of peptidoglycan and protected by the Outer membrane made up of lipoproteins and lipopolysaccharides (LPS) that act as permeability barrier $[10,11]$. On the other hand, Gram positive cell wall has thick layer of peptidoglycan and lacks outer membrane. Since it composed of peptidoglycan and teichoic acid, neither of it acts 
Page 4 of 4

as effective barrier that restrict the entry of detergent so high molecular substances can readily pass through it.

In addition, according to the result, the MICs and MBCs result of $K$. pneumonia, B. cereus and $S$. aureus, detergents in 96 well microtiter plates can inhibit the growth of bacteria with the lowest concentration that obtained from $S$. aureus. As mentioned by Andrew [12], the lower the MIC value, the higher the antibacterial activity. MIC is an important factor when it comes to choosing a detergent as it shows the effectiveness of the detergent towards pathogenic microorganism [12].

Meanwhile, as refer to Table 3, it shows that MBC values were higher than MIC values. This support the study made by French [13], which mentioned that antimicrobial agents can be regarded as bactericidal if the MBC value is not more than four times higher than MIC value. Therefore, D3 was the most effective in the inhibition of bacterial growth in single cell and to biofilm formation of the respective foodborne pathogens Therefore, in this study, MBEC values was defined as the lowest dilution at which bacteria fail to regrow in a biofilm form.

Biofilms are sessile microbial communities growing on surfaces that often embedded in a matrix of extracellular polymeric substances [14]. According to National Institutes of Health [15], approximately $80 \%$ of foodborne pathogens are able to form biofilm. In food industry, biofilms can create source of product contamination which leads to massive hygienic problems and economic losses due to food spoilage [16].

Therefore, the cleaning phase is the most important stage for reducing microbial colonization and for removing attached microorganism. In food handling operations, these detergents can be used as rinses, sprayed onto surfaces or circulated through equipment in Cleaning in Place (CIP) operations to prevent the microbial biofilm formation [17]. As mentioned by Gibson et al. [18], the use of detergents in cleaning procedure are not specifically designed as antimicrobial agents but instead to break down food soils, removes surface contamination, then followed by application of disinfectant to minimize the viability of the remaining organisms.

There are many types of detergents and each has different effects, so effective detergent is important to produce effective cleaning, save labour and low cost for cleaning the processing line. In some areas, detergent substances are biodegrade poorly and are associated with allergic reactions and skin and eye irritation. This data demonstrated the importance of choosing an appropriate and an effective detergent that aid removal of attached bacteria and reduce the viability of organisms have added benefits in terms of minimizing the generation of viable microorganism on food products surfaces and food processing line.

\section{Conclusion}

At the end of this study, it had been found that Detergent 3 [Linear alkylbenzene sulphonate (LAS)] based is the most effective detergent that could be used to eradicate bacterial biofilm of Klebsiella pneumonia, Bacillus cereus and Staphylococcus aureus. The effectiveness of detergents, especially as an antibacterial agent on the growth of single cells bacteria (MIC and MBC) to biofilm form
(MBEC) has been investigated. Thus, appropriates detergents should be selected to reduce and eliminate food safety hazard in relation any potential outbreak in future which includes prevention the transmission of diseases and infection due to the biofilm formation.

\section{Acknowledgement}

Research fund was sponsored by Small Grant Scheme (F07/(s170)/ 1269/2015(07), Universiti Malaysia Sarawak (Unimas) Kota Samarahan, Kuching Sarawak.

\section{References}

1. Carpentier B, Cerf O (1993) Biofilms and their consequences with particular reference to hygiene in the food industry. J Appl Bacteriol 75: 499-511.

2. Faille C, Julien C, Fontaine F, Bellon-Fontaine MN, Slomianny C, et al. (2002) Adhesion of Bacillus spores and Escherichia coli cells to inert surfaces: role of surface hydrophobicity. Can J Microbiol 48: 728-738.

3. Kuda T, Yano T, Kuda MT (2008) Resistances to benzalkonium chloride of bacteria dried with food elements on stainless steel surface. LWT 41: 988-993.

4. Humphrey TJ, Martin KW, Slader J, Durham K (2001) Campylobacter spp. in the kitchen: spread and persistence. J Appl Microbiol 90: 115-120.

5. Schneider KR, Parish ME, Goodrich RM, Cookingham T (2004) Preventing foodborne illness: Bacillus cereus and Bacillus anthracis.

6. Maris (1995) Laboratoire des Médicaments Vétérinaires, Ministère de l'Agriculture et de la Pêche, La Haute Marche, Javené, 35133 Fougères, France. Rev Sci Tech 14: 47-55.

7. Rukayadi Y, Lee K, Han S, Yong D, Huang JK (2009) In vitro activities of panduratin A against clinical Staphylococcus strains. Antimicrob Agents Chemother 53: 4529-4532.

8. Gaibraith H, Miller TB, Paton AM, Thompson JK (1971) Antibacterial activity of long chain fatty acids and the reversal with calcium, magnesium, ergocalciferol and cholesterol. J Appl Bacteriol 34: 808-813.

9. Garcia MT, Ribosa I, Campos E, Sanchez Leal (1997) Ecological properties of alkylpolyglucosides. Chemosphere 35: 545-556.

10. Sundheim G, Langsrud S, Heir E, Holck AL (1998) Bacterial resistance to disinfectants containing quaternary ammonium compounds. Int Biodet Biodeg 41: 235-239.

11. Braoudaki M, Hilton AC (2005) Mechanisms of resistance in Salmonella enterica adapted to erythromycin, benzalkonium chloride and triclosan. Int J Antimicrob Agents 25: 31-37.

12. Andrews JM (2001) Determination of minimum inhibitory concentrations. J Antimicrob Chemother 48: 5-16.

13. French GL (2002) Bactericidal agents in the treatment of MRSA infections-the potential role of daptomycin. J Antimicrob Chemother 58: 1107-1117.

14. Dunne WM (2002) Bacterial adhesion: seen any good biofilms lately? Clin Microbiol Rev 15: 155-66.

15. National Institute of Health (2002) Research on microbial biofilms: PA Number: PA-03-047.

16. Brooks JD, Flint SH (2008) Biofilms in the food industry: problems and potential solutions. Int J Food Sci Tech 43: 2163-2176.

17. Food Safety and Inspection Service (FSIS) (2002) Washington, DC: U. S. Department of Agriculture, Food Safety and Inspection service.

18. Gibson H, Taylor JH, Hall KE, Holah JT (1991) Effectiveness of cleaning techniques used in the food industry in terms of the removal of bacterial biofilms. J Appl Microbiol 87: 41-48. 